Krzysztof TOMASZEWSKI

DOI : $10.14746 /$ pp.2019.24.2.11

Uniwersytet Warszawski

ORCID ID: https://orcid.org/0000-0002-6324-1827

\title{
Problemy rozwoju elektromobilności w Polsce w kontekście krajowej polityki energetycznej
}

\begin{abstract}
Abstrakt: Artykuł dotyczy problematyki rozwijania elektromobilności w Polsce na tle planów związanych z kształtowaniem krajowej polityki energetycznej. Pojazdy elektryczne stanowią ważne wyzwanie dla polityki transportowej na świecie. Ich rosnąca popularność jest odpowiedzią na problemy zanieczyszczenia środowiska oraz ma związek z działaniami na rzecz zapewnienia zrównoważonego rozwoju. Polska jest państwem, które zamierza podążać w kierunku rozwijania transportu elektromobilnego. Przygotowano w tym celu odpowiednią strategię oraz ustanowiono prawo i wskazano instytucje odpowiedzialne w tym zakresie.

Niestety główna idea, jaka towarzyszy elektromobilności - czyli ekologia, nie idzie w parze z planami w zakresie polskiej polityki energetycznej. Zgodnie z oficjalnymi programami rządowymi, produkcja energii w Polsce do roku 2040 ma bazować na wykorzystaniu węgla. Oznacza to, że pojazdy elektryczne będą zasilane tzw. „brudną energią”. Hipoteza artykułu brzmi: rozwój elektromobilności w Polsce, trudno uzasadnić w kategoriach pozytywnego wpływu na środowisko naturalne i ochronę klimatu w sytuacji, kiedy wytwarzanie energii opiera się na węglu. Bez zmian w polityce energetycznej, elektromobilność „,po polsku” jest pomysłem nietrafionym, ponieważ nie spełnia podstawowych założeń - czyli nie przyczyni się do zmniejszenia negatywnego wpływu transportu na środowisko.
\end{abstract}

Słowa kluczowe: elektromobilność, pojazdy elektryczne, polityka transportowa, polityka energetyczna, zrównoważony rozwój

\section{Wstęp}

D ozwój floty nowoczesnych ekologicznych pojazdów, zasilanych w sposób, który -jest przyjazny środowisku, stanowi współcześnie jeden z głównych filarów działań państw rozwiniętych (zob. Komisja Europejska, 2017, s. 2-3). Jest to nie tylko kwestia czystego powietrza, ale również zmniejszenia ilości hałasu (zwłaszcza w miastach). Sposobów na zmianę sytuacji jest wiele, od represyjnych, np. zakazów lub ograniczeń wjazdu pojazdów spalinowych do centrów miast (takie działania wprowadzają w życie m.in. samorządy: Oslo, Kopenhagi, Hamburga, Amsterdamu); po bardziej pragmatyczne, np. rozwój transportu publicznego i zachęcanie obywateli do korzystania z tej formy przemieszczania się, rozbudowę systemu car sharingu, czy promowanie rowerów. Jednym z innowacyjnych sposobów w tym zakresie jest z pewnością wspomaganie elektromobilności. Ta ostatnia formuła ma na celu zachęcenie społeczeństwa oraz firm do większej otwartości wobec nowych rozwiązań technologicznych (Komisja Europejska, 2011, s. 3-4), które są oferowane na rynku motoryzacyjnym, ale z różnych względów (najczęściej z przyczyn finansowych) są stosunkowo mało popularne. Mowa przede wszystkim o pojazdach elektrycznych, które mają stać się podstawą polityki transportowej państw wysokorozwiniętych w przyszłości. 
Zamierzeniem badawczym niniejszego artykułu jest weryfikacja, w jakim zakresie perspektywa elektryfikacji transportu jest skorelowana z polityką energetyczną, na przykładzie Polski? Czy polski sektor energetyczny, który opiera się na wykorzystaniu węgla kamiennego stanowi dobrą bazę do rozwijania transportu o charakterze ekologicznym?

Problem badawczy artykułu należy zestawić z hipotezą główną: Rozwój elektromobilności w Polsce, gdzie ponad 80\% energii wytwarza się na bazie węgla kamiennego i brunatnego trudno uzasadnić w kategoriach pozytywnego wpływu na środowisko naturalne i ochronę klimatu. Bez zmian w polityce energetycznej, uwzględniających wymogi klimatyczne Unii Europejskiej, elektromobilność „,po polsku” wydaje się być pomysłem nieadekwatnym, w kontekście współczesnych wyzwań ekologicznych.

Metodologicznie artykuł oparty jest na analizie systemowej. Pozwala ona spojrzeć na postawione wyżej problemy przez prymat działań państwa (rządu - w szczególności) podejmowanych w zakresie polityk: energetycznej oraz transportowej (por. Kasianiuk, 2017, s. 169-192). Przedmiotem analizy jest rozwój elektromobilności w naszym kraju. Kluczowe $-\mathrm{z}$ badawczego punktu widzenia pozostaje pytanie, czy elektromobilność może przyczynić się dla środowiska i pozwoli lepiej chronić klimat. Czysta energia, która napędza czyste, ekologiczne pojazdy - oto cel, do którego należałoby dążyć mając na uwadze priorytety europejskie oraz światowe mega trendy w dziedzinie ekologii (Komisja Europejska, 2017, s. 3).

Analizowana problematyka jest szeroko traktowana w literaturze przedmiotu. Na przestrzeni ostatnich kilku lat stała się ona częścią głównego nurtu badań naukowych w obszarze nauk technicznych (np. Groger, Gasteiger, Suchsland, 2015; Schroeder, Traber, 2012). Stopniowo zyskuje ona coraz większą popularność w sferze nauk społecznych (np. Egbue, Long, 2012; Franke, Krems, 2013; Breetz, Salon, 2018; Cecere, Corrocher, Guerzoni, 2018). Bardzo popularne jest łączenie przez naukowców zagadnień sektora energii oraz ochrony klimatu (np. Prud'homme, Koning 2012; Canals-Casals, Martinez-Laserna, García, Nieto, 2016).

Wskazuje to na rosnące znaczenie tej problematyki w nauce, ale również na wzrost świadomości tego zjawiska w całym społeczeństwie. W Polsce badania nad elektromobilnością znajdują się $\mathrm{w}$ fazie początkowej, aczkolwiek na uwagę zasługują z pewnością prace: J. Murawskiego, E. Szczepańskiego (2014); K. Krawca, S. Krawca (2017), A. Gawlikowskiej-Fyk (2017).

\section{Strategia elektromobilności w Polsce}

Wprowadzanie zmian w polityce oraz odpowiednich dostosowań strukturalnych w gospodarce wymaga przyjęcia właściwej strategii działania, w której nakreślone zostaną zarówno cele, jak również sposoby ich osiągania w przewidzianym à priori horyzoncie czasowym. Sama strategia jest wszakże warunkiem koniecznym, aczkolwiek nie jedynym. Bez odpowiednich środków finansowych oraz adekwatnego zaplecza technologicznego, trudno jest ambitne plany wprowadzać w życie (zob. Murawski, Szczepański, 2014, s. 2249-2258).

Mówiąc o polskiej elektromobilności należy odwołać się do dokumentu przygotowanego w 2016 roku przez Ministerstwo Energii „Plan rozwoju elektromobilności w Pol- 
sce” (Ministerstwo Energii, 2016), który został przyjęty przez Radę Ministrów w marcu 2017 roku (dalej jako: „Plan...”). Jak wskazują źródła rządowe, jest on jednym z filarów „Strategii na rzecz Odpowiedzialnego Rozwoju” (Ministerstwo Infrastruktury i Rozwoju, 2017). Spełnia cechy wskazane powyżej, jako konstytutywne dla planu strategicznego. Według szacunków rządu, osiągnięcie liczby jednego miliona aut elektrycznych w Polsce do 2025 r. będzie wiązało się z wygenerowaniem dodatkowego popytu na energię na poziomie 4,3 TWh rocznie, co zapewni sektorowi dodatkowe 20 mld zł ze sprzedaży energii (zakładając średni okres eksploatacji auta na poziomie 10 lat). Pozyskane w ten sposób środki mogą zostać w części przeznaczone na finansowanie innowacji w sektorze energii.

Oprócz „Planu...” rząd przyjął również „Krajowe ramy polityki rozwoju infrastruktury paliw alternatywnych" (Ministerstwo Energii, 2017), które implementują regulacje europejskie (m.in. w zakresie warunków budowy infrastruktury dla paliw alternatywnych w polskich aglomeracjach) oraz dwie ustawy: pierwszą - o elektromobilności i paliwach alternatywnych z dnia 11 stycznia 2018 r. (Ustawa, 2018) oraz drugą - o zmianie ustawy o biokomponentach i biopaliwach ciekłych oraz niektórych innych ustaw z dnia 6 czerwca 2018 r., stanowiącą podstawę powołania Funduszu Niskoemisyjnego Transportu (dalej jako: Fundusz) (Ustawa, 2018a).

Pierwsza z nich ma sprzyjać rozwojowi elektromobilności oraz upowszechnić stosowanie innych paliw alternatywnych (np. LNG i CNG) w sektorze transportowym. Druga natomiast (poprzez ustanowienie Funduszu) ma wspierać rozbudowę infrastruktury paliw alternatywnych oraz tworzenie rynku pojazdów na te paliwa.

Według szacunków rządowych w trzydziestu dwóch wybranych aglomeracjach Polski, w roku 2020 (Ministerstwo Energii, 2017):

- w segmencie pojazdów napędzanych energią elektryczną: po drogach poruszać się będzie 50 tys. pojazdów, powstanie 6 tys. punktów o normalnej mocy ładowania, powstanie 400 punktów o dużej mocy ładowania;

- w segmencie aut napędzanych gazem ziemnym w postaci CNG: po drogach poruszać się będzie 3 tys. pojazdów, powstanie 70 punktów tankowania (por. Schroeder, Traber, 2012, s. 136-144).

Prognozy ministerialne sięgają dalej - do roku 2025. Oszacowano, że w skali ogólnopolskiej (Ministerstwo Energii, 2017):

- W segmencie aut napędzanych energią elektryczną: po drogach poruszać się będzie jeden milion pojazdów elektrycznych;

- w segmencie aut napędzanych gazem ziemnym w postaci CNG: po drogach poruszać się będzie 54 tys. pojazdów, dostępne będą 32 punkty ładowania wzdłuż sieci bazowej TEN-T;

- w segmencie aut zasilanych LNG: po drogach poruszać się będzie 3 tys. pojazdów. Resort energii wskazuje przy tym, iż w praktyce punkt ciężkości zostanie położony na infrastrukturę w dużych aglomeracjach i wzdłuż transeuropejskich korytarzy transportowych przebiegających przez obszar Polski. Równolegle „Plan...” proponuje narzędzia rozwoju rynku pojazdów elektrycznych, które doprowadzą do wzrostu ilości pojazdów elektrycznych w momencie, gdy gotowa będzie istotna część infrastruktury. Dodatkowo, uwzględniono kwestię powiązania rozwoju przemysłu elektromobilności i rynku pojazdów z rozwojem sieci elektroenergetycznej. Zgodnie z zapowiedziami, 
zawartymi w „Planie...”, zachęty do zakupu pojazdów mają zostać zintensyfikowane w momencie, gdy przemysł będzie gotów odpowiedzieć na wygenerowany przez instrumenty wsparcia popyt, a sieć będzie mogła obsłużyć rosnące zapotrzebowanie na energię do ładowania pojazdów.

Reasumując, plany strategiczne wydają się dobrze przygotowane, poparte odpowiednią legislacją wraz ze wskazaniem środków finansowych, jakie potencjalnie niezbędne są do wypracowania zakładanych efektów. Plany te wydają się równocześnie bardzo ambitne w zestawieniu z realiami polskiej gospodarki oraz sytuacją materialną społeczeństwa. Uwzględnienie tych dwóch aspektów wydaje się z kolei kluczowe dla efektywnej realizacji takiej strategii (por. Schroeder, Traber, 2012, s. 137-140).

\section{Perspektywy polityki energetycznej do 2040 roku}

Plany rozwoju elektromobilności w Polsce należałoby zestawić ze strategią działań w zakresie sektora energetycznego. Podstawowe znaczenie w tym zakresie ma bez wątpienia „Polityka energetyczna Polski do 2040 roku” (dalej jako: PEP 2040). Odpowiedni projekt został przygotowany przez Ministerstwo Energii w listopadzie 2018 roku i poddany konsultacjom społecznym. PEP 2040 jest jedną z dziewięciu zintegrowanych strategii sektorowych, wynikających ze „Strategii na Rzecz Odpowiedzialnego Rozwoju”. PEP 2040 jest zgodna z dokumentami strategicznymi Unii Europejskiej (Ministerstwo Energii, 2018).

\section{Wykres 1. Prognoza zużycia węgla kamiennego w elektrowniach i elektrociepłowniach} w ujęciu rocznym oraz skumulowane w latach 2020-2040

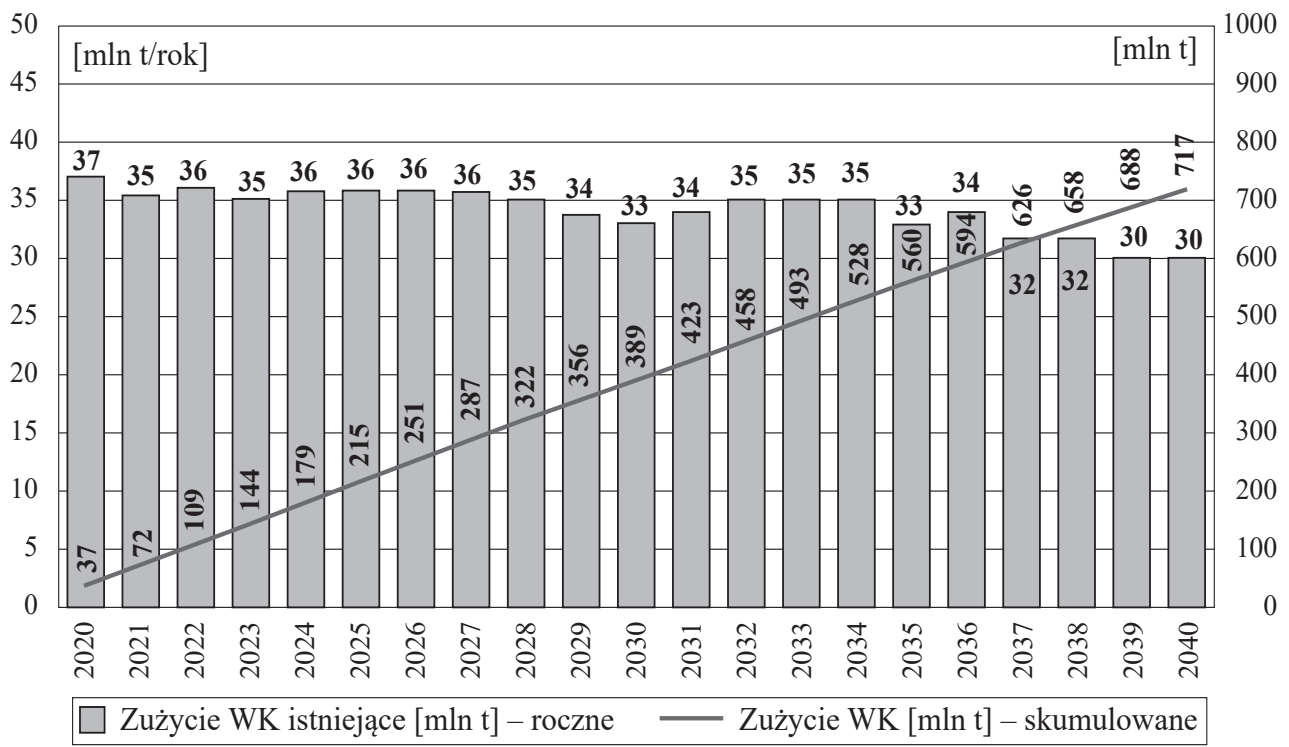

Źródło: Wnioski z analiz prognostycznych dla sektora energetycznego - zał. nr 1 do Polityki energetycznej Polski do 2040 roku (wersja z dn. 23.11.2018) (Ministerstwo Energii, 2018a, s. 12). 
Bliższa analiza strategii wskazuje, że do roku 2030 udział węgla w wytwarzaniu energii elektrycznej w Polsce będzie wynosił $60 \%$. Odnawialne źródła energii natomiast mają stanowić $21 \%$ w finalnym zużyciu energii brutto w 2030 r. Dodatkowo Ministerstwo planuje wdrożenie energetyki jądrowej w 2033 r. oraz poprawę efektywności energetycznej o $23 \%$. W dokumencie podtrzymano również plan budowy nowego węglowego bloku energetycznego o mocy $1000 \mathrm{MW}$, w elektrowni Ostrołęka.

Plany rządowe, związane $\mathrm{z}$ wykorzystaniem węgla w gospodarce, wskazują jednoznacznie, iż surowiec ten będzie stanowił podstawę produkcji energii w najbliższych latach. Nie zmieni tego zasadniczo, ani perspektywa budowy elektrowni jądrowej, ani również stosunkowo niewielkie wykorzystanie energii ze źródeł odnawialnych.

Jeśli dodatkowo zestawić dane Ministerstwa Energii z prognozami dotyczącymi zapotrzebowania na energię w najbliższych latach (wykres 2), można odnieść wrażenie, iż bezpieczeństwo energetyczne Polski będzie w kolejnych latach nadal uzależnione od surowca, który w Unii Europejskiej uznawany jest za podstawowy nośnik tzw. „brudnej energii”.

\section{Wykres 2. Prognoza zapotrzebowania na energię elektryczną w Polsce perspektywie} do 2040 roku

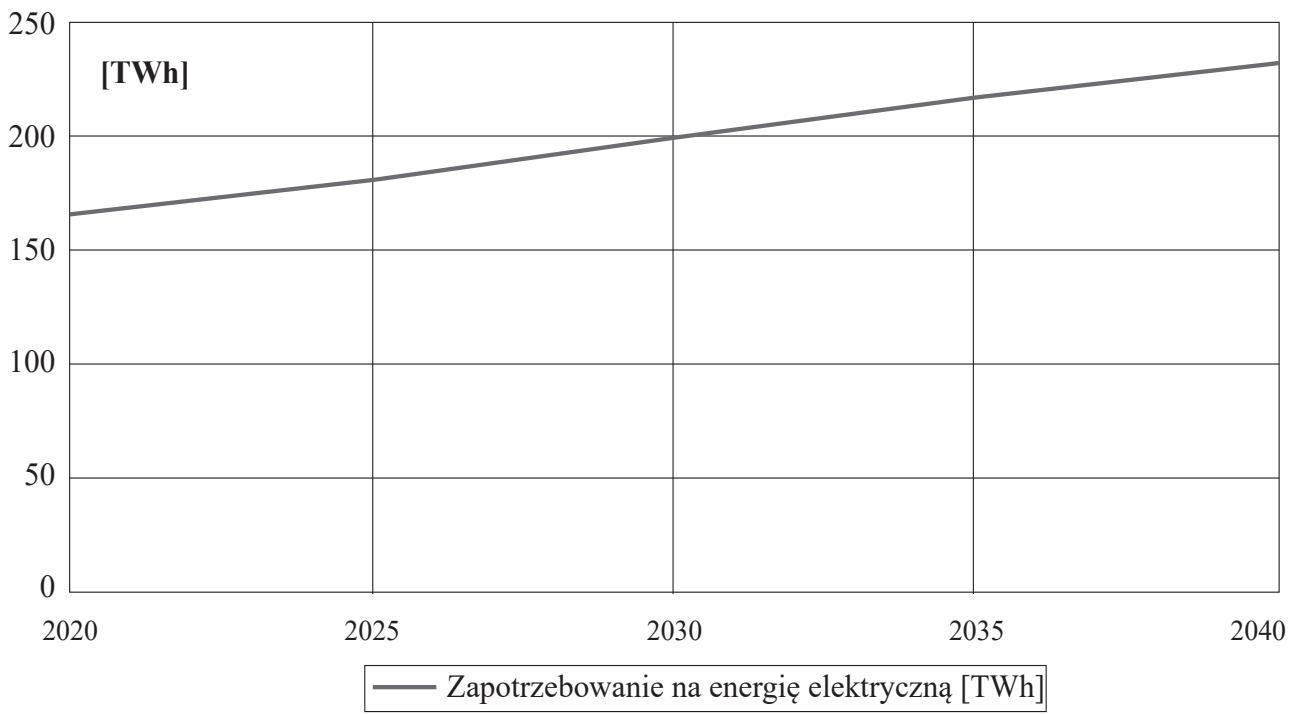

Źródło: Wnioski z analiz prognostycznych dla sektora energetycznego, Zał. $\mathrm{nr} 1$ do Polityki energetycznej Polski do 2040 roku (wersja z dn. 23.11.2018) (Ministerstwo Energii, 2018a, s. 12).

Taka struktura bilansu energetycznego może być oczywiście uzasadniana kwestiami bezpieczeństwa energetycznego Polski. Jest ono w dużej mierze uzależnione od wykorzystania krajowych zasobów surowców energetycznych. Teza ta znajduje zresztą odzwierciedlenie w PEP 2040, gdzie zapisano, iż krajowe zasoby węgla pozostaną głównym elementem bezpieczeństwa energetycznego Polski i będą podstawą bilansu energetycznego państwa (PEP 2040, s. 15). Ministerstwo Energii zapewnia jednocześnie, że roczne zużycie węgla kamiennego w energetyce zawodowej nie będzie zwiększane, 
ale ze względu na wzrost zapotrzebowania na energię elektryczną zmieni się udział węgla w strukturze. Za pozytywne można uznać natomiast to, iż inwestycje w nowe bloki węglowe podejmowane po $2025 \mathrm{r}$. będą oparte o wytwarzanie w skojarzeniu lub inną technologią spełniającą standard emisyjny na poziomie $450 \mathrm{~kg} \mathrm{CO}_{2}$ na MWh wytworzonej energii.

Twórcy PEP 2040, dla zrównoważenia negatywnego odbioru dokumentu (w związku z pomysłami na znaczne zastosowanie węgla) wskazują, iż dla jak najlepszego wykorzystania surowca oraz ograniczenia wpływu na środowisko poszukiwane i wykorzystywane będą nowe metody spalania węgla tj. zgazowanie, oksyspalanie, inne czyste technologie węglowe (PEP, 2040, s. 15). Nie pojawiają się żadne bliższe szczegóły, dotyczące wykorzystania tego typu technologii, zwłaszcza w kontekście potencjalnych kosztów.

Gdyby Polska rzeczywiście zastosowała takie rozwiązania byłaby z pewnością w światowej awangardzie przemysłu energetycznego. Nie sposób zatem nie odnieść wrażenia, iż ten ostatni argument stanowi raczej przejaw myślenia życzeniowego, aniżeli wyraz racjonalnej oceny możliwości polskiej gospodarki.

\section{Wykres 3. Udzial energii z OZE w elektroenergetyce w latach 2007-2016 (Polska i UE)}

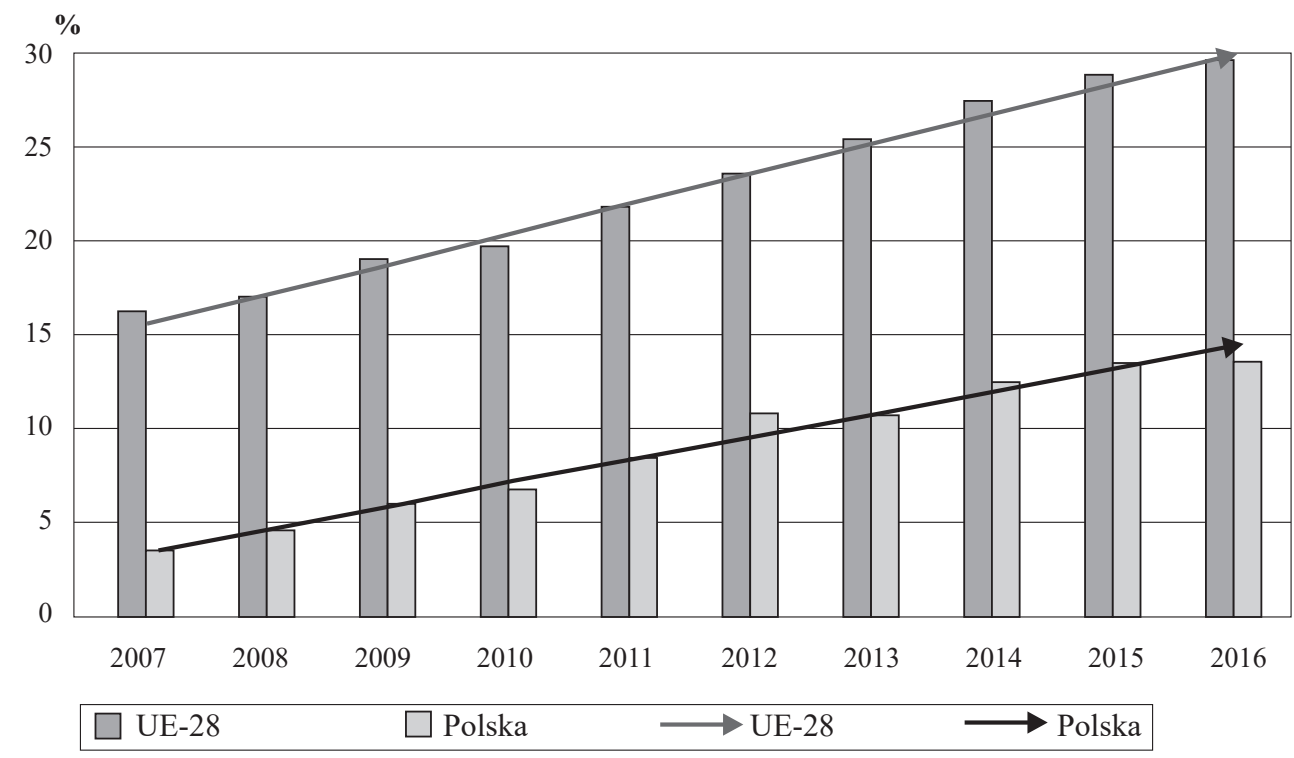

Źródło: GUS, Raport: Energia 2018, Warszawa.

Reasumując, perspektywy polityki energetycznej Polski do 2040 roku nie wskazują na gruntowną zmianę postawy decydentów w odniesieniu do znaczenia węgla w polskim bilansie energetycznym. Można to uznać z jednej strony za przejaw realizmu politycznego i zdrowego rozsądku elit politycznych, ale można również postrzegać krytycznie - jako brak myślenia perspektywicznego, niedostrzeganie mega trendów energetycznych i prawidłowości, jakie zachodzą na rynku światowym w cywilizowanych i rozwiniętych krajach. Mowa przede wszystkim o rozwijaniu technologii odnawialnych (zob. wykres 3) i działaniu na rzecz ochrony środowiska naturalnego. 


\section{Między strategią polityczną a realiami ekonomicznymi}

Ambitne plany rozwoju polityki transportowej w oparciu o flotę pojazdów elektrycznych wymagają, aby skonfrontować je z realiami polskiej gospodarki, zwłaszcza w kontekście sektora energetycznego. Konfrontacja tego rodzaju oznacza konieczność postawienia pytania: czy mega trendy można traktować w sposób wybiórczy? To znaczy, $\mathrm{z}$ jednej strony działać w kierunku elektryfikacji transportu; jednocześnie - $\mathrm{z}$ drugiej strony - zachowywać konserwatywną postawę w odniesieniu do modernizacji sektora energetycznego?

Problemy w rozwoju elektromobilności na świecie są bardzo liczne. Wystarczy wymienić choćby: stosunkowo ograniczony zasięg tego typu pojazdów (pokonywany na jednym ładowaniu) (Groger, Gasteiger, Suchsland, 2015, s. 2606) wysoka cena zakupu (w porównaniu do pojazdów zasilanych napędem spalinowym) (zob. Cecere, Corrocher, Guerzoni, 2018, s. 19-32), długi czas ładowania (w przypadku podróży na duże odległości), brak dostatecznie rozwiniętej infrastruktury drogowej do ładowania baterii (zob. Franke, Krems, 2013, s. 56-62), brak efektywnej możliwości ładowania pojazdów dla mieszkańców budownictwa wielorodzinnego (zob. Egbue, Long, 2012, s. 717-729). W Polsce do tych wszystkich problemów należałoby dodać kwestie stosunkowo przestarzałego parku użytkowanych pojazdów.

Jak wynika z raportu Polskiego Związku Przemysłu Motoryzacyjnego (dalej jako: PZPM), opublikowanego w 2018 roku, średni wiek samochodu osobowego w 2017 roku wynosił w Polsce 13,8 roku (o 0,2 roku więcej niż w 2016 roku), natomiast mediana sięgała czternastu lat (Raport PZPM, 2019, s. 24). Starszymi autami niż Polacy jeżdżą w Europie kierowcy na Węgrzech, w Czechach i Chorwacji, a najstarsze samochody mają kierowcy w Rumunii (16,2 roku) i na Litwie (16,9 roku). Najnowszymi pojazdami podróżują natomiast mieszkańcy Luksemburga (6,3 roku), Wielkiej Brytanii (7,8 roku) i Austrii (8,2 roku) (AMiS, 2019, s. 24).

\section{Wykres 4. Struktura wiekowa samochodów osobowych w Polsce na koniec 2017 roku} w procentach

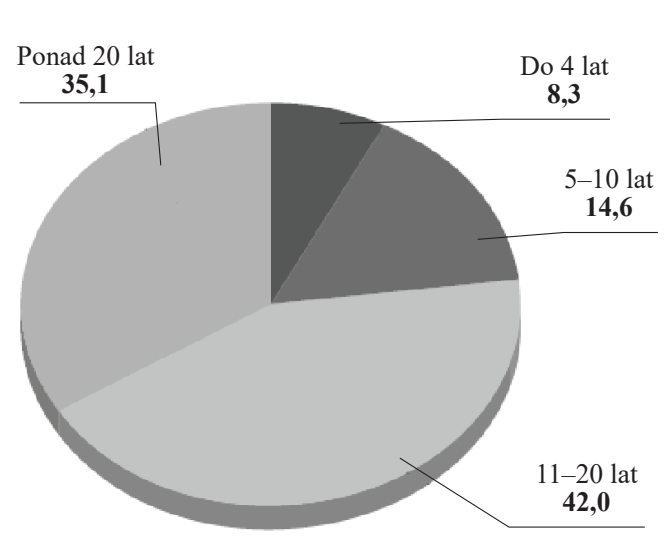

Cały park

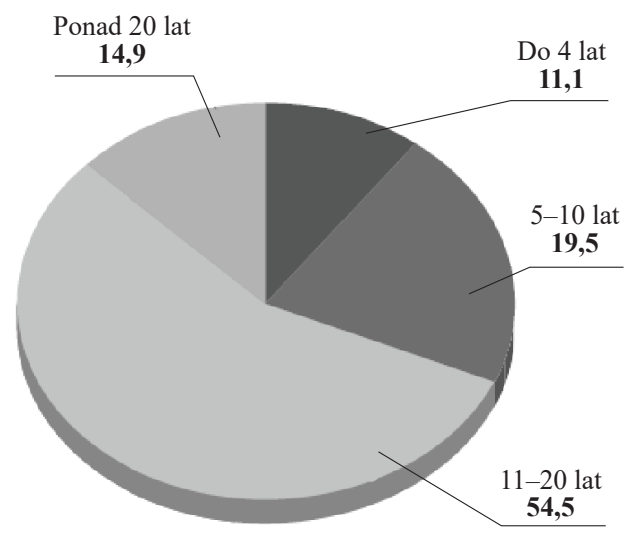

W tym zaktualizowane

Źródło: Analizy PZPM na podstawie danych CEP, cyt. za Raport PZPM, 2019, s. 24. 
Przechodząc do polskiej statystyki, samochody osobowe 4-letnie lub młodsze stanowiły na koniec 2017 roku 11,1\% parku pojazdów osobowych. Było to o 0,5\% mniej niż na koniec 2016 roku. Starzejący się od wielu lat park samochodowy zasilany jest głównie przez import, w którym przeważają auta ponad 10-letnie. Konsekwencje utrzymywania starego parku samochodów są ponoszone nie tylko przez właścicieli samochodów (często w postaci wyższych rachunków za naprawy), ale i społeczeństwo (zob. wykres 4). Stare samochody są mniej bezpieczne i nieekologiczne. Rozregulowane silniki emitują znacznie więcej trujących spalin, niż nowe modele (Raport PZPM, 2019, s. 24).

Problem wieku używanych pojazdów w Polsce nie jest jedynym, nad którym należy zastanawiać się w kontekście planów wprowadzania elektromobilności.

Kolejnym jest z pewnością kwestia popularności poszczególnych rodzajów paliwa w Polsce. Jak podaje w raporcie PZPM, w parku aut osobowych w podziale na rodzaj paliwa, na koniec 2017 roku 46\% stanowiły modele z silnikami benzynowymi, na diesel przypadło $39 \%$, na LPG 14\%, zaś na inne napędy $1 \%$. Liczba aut na benzynę i LPG (łącznie) wzrosła o 6,1\%, natomiast diesli o 7,6\%. Wśród samochodów najmłodszych, liczących do czterech lat, napęd benzynowy miało 60\% (o 2\% więcej niż rok wcześniej), wysokoprężny 35\% (o 2\% mniej niż w 2016 roku), natomiast na LPG przypadło tylko $4 \%$ floty. Pojazdy hybrydowe zdobyły $1 \%$ tego segmentu. W grupie aut liczących od pięciu do dziesięciu lat najliczniejsze były modele $\mathrm{z}$ napędem wysokoprężnym miały 51\% udziału (o 1\% mniej niż rok wcześniej). Na koniec 2017 roku benzynowe modele zdobyły 41\% segmentu (o 2\% więcej w stosunku do 2016 roku). Modele napędzane LPG stanowiły $7 \%$, to jest o $1 \%$ mniej niż rok wcześniej.

Popularność paliw kopalnych, zwłaszcza benzyny wydaje się niezagrożona w najbliższych latach. Nieco słabiej prezentuje się zainteresowanie silnikami diesla, które w publicznej debacie prezentowane są, jako źródło napędu szczególnie obciążające środowisko, z uwagi na szkodliwe emisje. Ten dyskurs pojawił się w szczególności po tzw.

\section{Wykres 5. Struktura rejestracji aut osobowych w Polsce wg napędu w procentach}

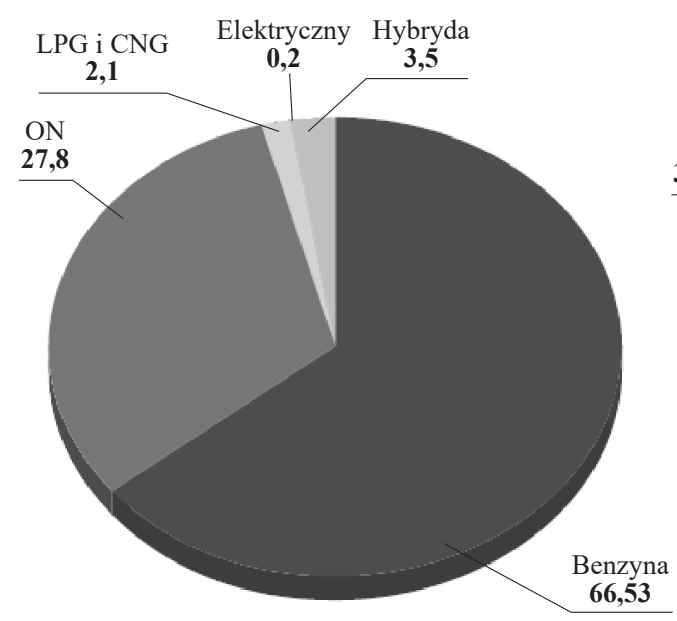

2017

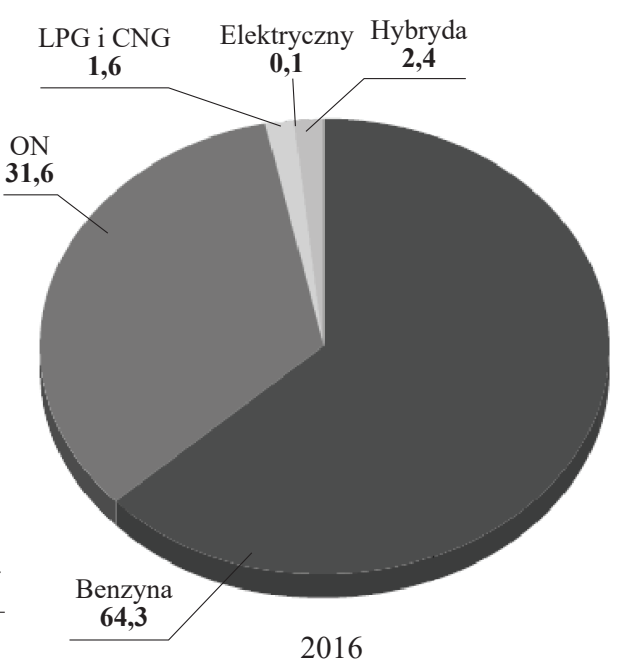

2016

Źródło: Analizy PZPM na podstawie danych CEP, cyt. za Raport PZPM, 2019, s. 31. 
aferze Volkswagena (zwanej również: Dieselgate), który fałszował wyniki badań emisji spalin w swoich silnikach wysokoprężnych (zob. Barret i in., 2015).

Z danych dotyczących rejestracji nowych pojazdów w 2017 roku, można wyczytać, że osłabienie zainteresowania silnikami wysokoprężnymi wzmacnia pozycję napędów benzynowych oraz hybrydowych. Udział pojazdów z silnikami benzynowymi w rejestracjach w 2017 roku wzrósł o 2\% do 66\%. Rok do roku rejestracje aut z napędem benzynowym zwiększyły się o 20,7\%. Wyraźnie wzrasta popyt na hybrydy. Liczba rejestracji tych samochodów sięgnęła 16,9 tys. i była o 68,1\% większa niż w 2016 roku. Udział hybryd w całości rejestracji wyniósł 3,5\% i jest o ponad $1 \%$ większy od udziału samochodów z fabryczną instalacją LPG (Raport PZPM, 2019, s. 31).

Z punktu widzenia ochrony środowiska za optymistyczne można uznać zwiększenie rejestracji pojazdów hybrydowych w Polsce, choć (jak widać na wykresie 5) ten rodzaj napędu ma dotychczas symboliczny udział w strukturze pojazdów poruszających się po drogach Polski.

Oceniając sytuację realistycznie, wzrost zainteresowania pojazdami elektrycznymi wydaje się mało prawdopodobny w perspektywie, którą określił rząd w dokumentach strategicznych. Wynika to przede wszystkim z przestarzałej struktury parku samochodowego oraz ograniczonej możliwości zakupu pojazdów elektrycznych, których ceny są stosunkowo wysokie w porównaniu do analogicznych pojazdów z danego segmentu, wykorzystujących napęd spalinowy (por. Cecere, Corrocher, Guerzoni, 2018, s. 20-31).

\section{Podsumowanie}

Perspektywa modernizacji polskiego transportu w kierunku elektromobilności jest kierunkiem działania, który należy uznać za zgodny z tendencjami panującymi na świecie, zwłaszcza w państwach wysokorozwiniętych (por. Prud'homme, Koning, 2012, s. 60-69). Ograniczanie szkodliwego wpływu transportu na środowisko wydaje się jednym z głównych filarów w dyskusji na temat zrównoważonego rozwoju i ochrony klimatu, która toczy się w ramach Konferencji Narodów Zjednoczonych w sprawie zmian klimatu (tzw. COP) (zob. Ghezlouna, Saidane, Merabeta, 2017, s. 10-16). Plany strategiczne, którymi dysponuje w tym zakresie Polska, należy oceniać jako ambitne i adekwatne do mega trendów światowych. Niestety, konfrontacja idei z rzeczywistością skłania do wniosków znacznie bardziej pesymistycznych i krytycznych.

Po pierwsze - strategia. Ta dotycząca elektromobilności wydaje się mocno oderwana od realiów ekonomicznych Polski i bliższa jest tzw. myślenia życzeniowego, aniżeli realnego planu polityczno-gospodarczego, który może być efektywnie realizowany.

Po drugie - polskie plany w zakresie elektromobilności nie są, jak się wydaje, efektywnie skorelowane z planami w zakresie polityki energetycznej, przynajmniej jeśli wziąć pod uwagę aspekty środowiskowe. O ile działania na rzecz bezpieczeństwa energetycznego - rozumiane jako zapewnienie niezakłóconych dostaw energii dla obywateli i firm należy uznać za pragmatyczne, o tyle trudno dostrzec powiązanie strategii energetycznej z kwestiami ochrony środowiska, które z kolei mają naczelne znaczenie z punktu widzenia zwiększania zaangażowania państwa w promowanie pojazdów elektrycznych. 
Po trzecie - należałoby zastanowić się nad potencjalną grupą docelową odbiorców elektromobilności w Polsce. Można byłoby ich podzielić zasadniczo na trzy kategorie. Pierwszą stanowią firmy działające w obszarze car sharingu, zajmujące się krótkoterminowym wynajmowaniem aut. Podmioty tego typu, operujące na kilku czy kilkunastu rynkach europejskich mogą budować swoje floty z uwzględnieniem postulatów elektromobilności. W ich przypadku ma to sens, ponieważ pojazdy wykorzystywane są najczęściej w miastach (nie ma więc problemu ograniczonego zasięgu), poza tym - negocjowana z producentami - cena przy zakupach wolumenowych takich aut może być znacznie korzystniejsza, niż w przypadku odbiorców indywidualnych, a ponadto pojawia się kwestia PR i dobrego wizerunku. Oparty na elektromobilności car sharing może być kojarzony jako ekologiczna alternatywa dla pojazdów spalinowych (zob. Canals Casals, Martinez-Laserna, García, Nieto, 2016, s. 435-437).

Drugą kategorią odbiorców zainteresowanych pojazdami elektrycznymi mogą być polskie przedstawicielstwa międzynarodowych korporacji. Mają one często w swojej filozofii podejmowanie działań na rzecz ochrony środowiska, poszanowania klimatu, czy ograniczania emisji $\mathrm{CO}_{2}$. Do tej kategorii odbiorców można byłoby zakwalifikować, na przykład, takie przedsiębiorstwa, jak: Ikea (2018) czy Castorama (2017).

Trzecią grupą nabywców pojazdów elektrycznych będą z pewnością urzędy państwowe oraz samorządy. Taki scenariusz wynika bezpośrednio z zapisów ustawy o elektromobilności, która systemowo zakłada uzupełnianie floty samochodów urzędów i samorządów o pojazdy napędzane elektrycznie (art. 34-36, Ustawa 2018).

Wydaje się, że polski rząd ma świadomość, że plany rozwoju elektromobilności mogą być zagrożone, dlatego też powstała koncepcja, aby nabywcy samochodów elektrycz-

\section{Wykres 6. Kwoty, jakie Polacy przeznaczają na zakup samochodu (2018 rok)}

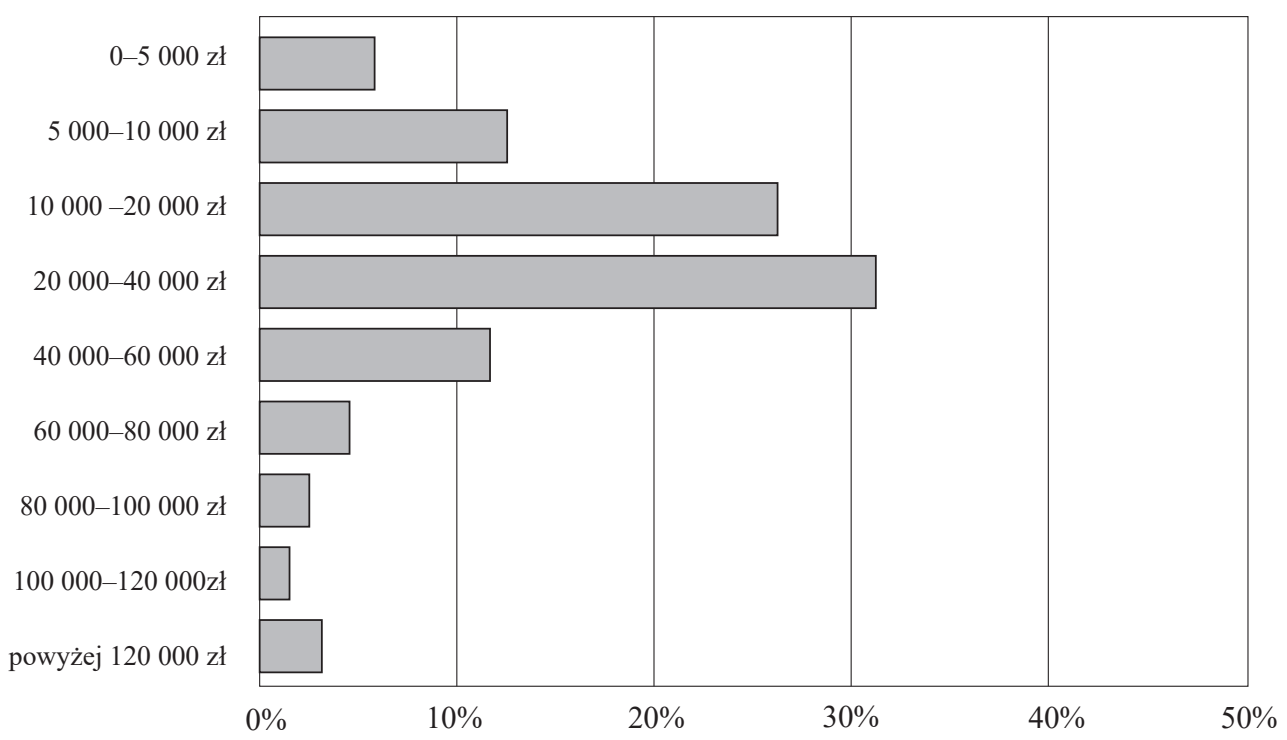

Źródło: Badanie sondażowe Motofocus.pl i Otomoto.pl, 26.10.2018, https://motofocus.pl/informacje/nowosci/67951/polacy-kupuja-samochody-coraz-odpowiedzialniej. 
nych mogli uzyskać refundację takiego zakupu do wysokości maksymalnie 36 tys. PLN (por. Breetz, Salon, 2018, s. 238-240). Taka rekompensata, choć wydaje się atrakcyjna, nie zmienia faktu, iż ceny pojazdów elektrycznych nadal pozostają znacząco wyższe, niż średnie kwoty, jakie Polacy przeznaczają na zakup samochodu. Z badania sondażowego przeprowadzonego w 2018 roku na grupie 3,5 tys. osób (zob. wykres 6) przez firmę OTOMOTO, która działa na polskim rynku ogłoszeń motoryzacyjnych (dysponując bazą ofert od dealerów, komisów samochodowych i indywidualnych sprzedawców) oraz portal branżowy Motofocus.pl wynika, że większość badanych deklaruje chęć zakupu auta w przedziale 10-20 lub 20-40 tys. zł. Tylko nieco ponad 12,5\% osób zamierza wydać na samochód więcej niż 60 tys. zł. Co ciekawe, niewielka jest także grupa osób deklarujących zakup bardzo taniego samochodu - do 5 tys. zł (5,77\%) (Motofocus.pl, 2018).

Reasumując powyższe, zaprezentowana we wstępie do artykułu hipoteza wydaje się w pełni uzasadniona. Elektromobilność - jako idea zasługuje z pewnością na wsparcie (zob. Raport FPPE-CE, 2018). Jest to idea, która promuje zrównoważony rozwój i ochronę klimatu, i - z pewnością - otwiera nowy etap w dziedzinie polityki transportowej (por. Gawlikowska-Fyk, 2017).

Jednak jej praktyczna realizacja wydaje się znacznie trudniejsza, aniżeli wynikałoby to z lektury rządowych strategii. Jest ona bowiem uwarunkowana możliwościami finansowymi społeczeństwa oraz ogólnym poziomem rozwoju gospodarczego (zob. Krawiec, Krawiec, 2017, s. 18-14). Ponadto, aby wdrożenie tej idei miało sens z ekologicznego punktu widzenia, kluczowe jest odpowiednie dostosowanie polityki energetycznej. Komisja Europejska w swojej narracji politycznej nazywa to „synergią między infrastrukturą transportową, energetyczną i telekomunikacyjną" (Komisja Europejska, 2017, s. 18).

Samochody elektryczne są ekologiczne w takim samym stopniu, jak energia, która je zasila. Myśląc o ochronie klimatu, trudno wyobrazić sobie, aby energia produkowana z węgla stanowiła odpowiednią podstawę dla rozwijania elektromobilności.

\section{Bibiliografia}

AMiS (2019), Raport: Wiek samochodów w Europie, „Auto Motor i Sport”, nr 4, s. 24.

Barrett S. R., Speth R. L., Eastham S. D., Dedoussi I. C., Malina R., Keith D. W. (2015), Impact of the Volkswagen emissions control defeat device on US, "Environmental Research Letters", vol. 10, ss. $1-10$.

Breetz H. L., Salon D. (2018), Do electric vehicles need subsidies? Ownership costs for conventional, hybrid, and electric vehicles in 14 U.S. cities, "Energy Policy", vol. 120 (September), ss. 238-249.

Canals Casals L., Martinez-Laserna E., García B., Nieto N. (2016), Sustainability analysis of the electric vehicle use in Europe for $\mathrm{CO}_{2}$ emissions reduction, "Journal of Cleaner Production", vol. 127 (July), ss. 425-437.

Castorama (2017), Polityka zrównoważonego rozwoju, https://www.castorama.pl/castorama/zrownowazony-rozwoj/polityka-zrownowazonego-rozwoju, 26.03.2019.

Cecere G., Corrocher N., Guerzoni M. (2018), Price or performance? A probabilistic choice analysis of the intention to buy electric vehicles in European countries, "Energy Policy", vol. 118 (July), ss. 19-32. 
Franke T., Krems J. F. (2013), What drives range preferences in electric vehicle users?, "Transport Policy”, vol. 30 (November), ss. 56-62.

Egbue O., Long S. (2012), Barriers to widespread adoption of electric vehicles: An analysis of consumer attitudes and perceptions, "Energy Policy", vol. 48 (September), ss. 717-729.

Gawlikowska-Fyk A. (2017), Samochody elektryczne w Niemczech-jazda pod prad, „Biuletyn PISM”, nr 105 (1547).

Ghezlouna A., Saidane A., Merabeta H. (2017), The COP 22 New commitments in support of the Paris Agreement, "Energy Procedia", vol. 119 (July), ss. 10-16.

Groger O., Gasteiger H. A. Suchsland J.-P. (2015), Review - Electromobility: Batteries or Fuel Cells?, "Journal of The Electrochemical Society", 162 (14), ss. 2605-2622.

GUS (2018), Raport: Energia, Główny Urząd Statystyczny, Warszawa.

Ikea (2018), Ikea Sustainability Strategy - People \& Planet Positive, Inter Ikea Systems B.V., https:// www.ikea.com/ms/pl_PL/pdf/people_planet_positive/IKEA_Sustainability_Strategy_People_ Planet_Positive_v3.pdf, 26.03.2019.

Kasianiuk K. (2017), Analiza systemowa jako narzędzie w badaniach instytucji politycznych, „Studia Polityczne", nr 2 (45), ss. 169-192.

Komisja Europejska (2011), Biała księga: Plan utworzenia jednolitego europejskiego obszaru transportu - dążenie do osiagnięcia konkurencyjnego i zasobooszczędnego systemu transportu, COM (144) 2011.

Komisja Europejska (2017), Komunikat: Europa w ruchu. Program działań na rzecz sprawiedliwego społecznie przejścia do czystej, konkurencyjnej i opartej na sieci mobilności dla wszystkich, COM (283) 2017.

Krawiec K., Krawiec S. (2017), Rozwój elektromobilności w Polsce. Uwarunkowania, cele i barie$r y$, „Studia Ekonomiczne. Zeszyty Naukowe Uniwersytetu Ekonomicznego w Katowicach”, nr 332, ss. 17-24.

Ministerstwo Energii (2016), Plan rozwoju elektromobilności w Polsce. Energia do przyszłości (dokument przyjęty przez Radę Ministrów 16 marca 2017 r.).

Ministerstwo Energii (2017), Krajowe ramy polityki rozwoju infrastruktury paliw alternatywnych (dokument przyjęty przez Rada Ministrów 29 marca 2017 r.).

Ministerstwo Energii (2018), Polityka energetyczna Polski do 2040 roku, projekt v. 1.2., 23.11.2018, https://www.gov.pl/web/energia/polityka-energetyczna-polski-do-2040-r-zapraszamy-dokonsultacji, 18.03.2019.

Ministerstwo Energii (2018a), Wnioski z analiz prognostycznych dla sektora energetycznego - załącznik nr 1 do Polityki energetycznej Polski do 2040 roku, projekt v. 1.2., 23.11.2018, https:// www.gov.pl/web/energia/polityka-energetyczna-polski-do-2040-r-zapraszamy-do-konsultacji, 18.03.2019.

Ministerstwo Infrastruktury i Rozwoju (2017), Strategia na rzecz Odpowiedzialnego Rozwoju do roku 2020 (z perspektywa do 2030 r.) (dokument przyjęty przez Radę Ministrów 14 lutego 2017 r.).

Motofocus.pl (2018), Polacy kupuja samochody coraz odpowiedzialniej, https://motofocus.pl/informacje/nowosci/67951/polacy-kupuja-samochody-coraz-odpowiedzialniej, 18.03.2019.

Murawski J., Szczepański E. (2014), Perspektywy dla rozwoju elektromobilności w Polsce, „Logistyka”, nr 4, ss. 2249-2258.

Prud'homme R., Koning M. (2012), Electric vehicles: A tentative economic and environmental evaluation, „Transport Policy”, vol. 23 (September), ss. 60-69.

Raport FPPE-CE (2018), Napędzamy polska przyszłość, Fundacja Promocji Pojazdów Elektrycznych i Cambridge Econometrics, Warszawa.

Raport PZPM (2019), Raport 2018. Branża motoryzacyjna, Polski Związek Przemysłu Motoryzacyjnego, Warszawa. 
Schroeder A., Traber T. (2012), The economics of fast charging infrastructure for electric vehicles, „Energy Policy”, vol. 43 (April), ss. 136-144.

Tomaszewski K. (2017), Autonomous vehicles as a challenge for the transport policy of the European Union, „Przegląd Europejski”, nr 4 (46), ss. 76-95.

Ustawa (2018), Ustawa o elektromobilności i paliwach alternatywnych, Dz. U. 2018, poz. 317.

Ustawa (2018a), Ustawa o zmianie ustawy o biokomponentach $i$ biopaliwach ciektych oraz niektórych innych ustaw, Dz. U. 2018, poz. 1356.

\title{
Problems of Electromobility Development in Poland in the Context of National Energy Policy
}

\begin{abstract}
Summary
The article concerns the issue of developing electromobility in Poland against the background of plans related to shaping the national energy policy. Electric vehicles are an important challenge for transport policy in the world. Their growing popularity is a response to the problems of environmental pollution and is associated with activities to ensure sustainable development. Poland is a State that intends to move towards the development of electromobile transport. An appropriate strategy was prepared for this purpose, and the law was established and the responsible institutions were identified in this regard.

Unfortunately, the main idea that accompanies electromobility - that is, ecology, does not go hand in hand with plans in the field of Polish energy policy. According to official government programs, energy production in Poland until 2040 is to be based on the use of coal. This means that electric vehicles will be powered by the so-called "dirty energy". The hypothesis of the article is that the development of electromobility in Poland is difficult to justify in terms of a positive impact on the natural environment and climate protection in a situation where energy production is based on coal. Without changes in energy policy, electromobility "in Polish" is a failed idea, because it does not meet the basic assumptions - that is, it will not contribute to reducing the negative impact of transport on the environment.
\end{abstract}

Key words: electromobility, electric vehicles, transport policy, energy policy, sustainable development 
